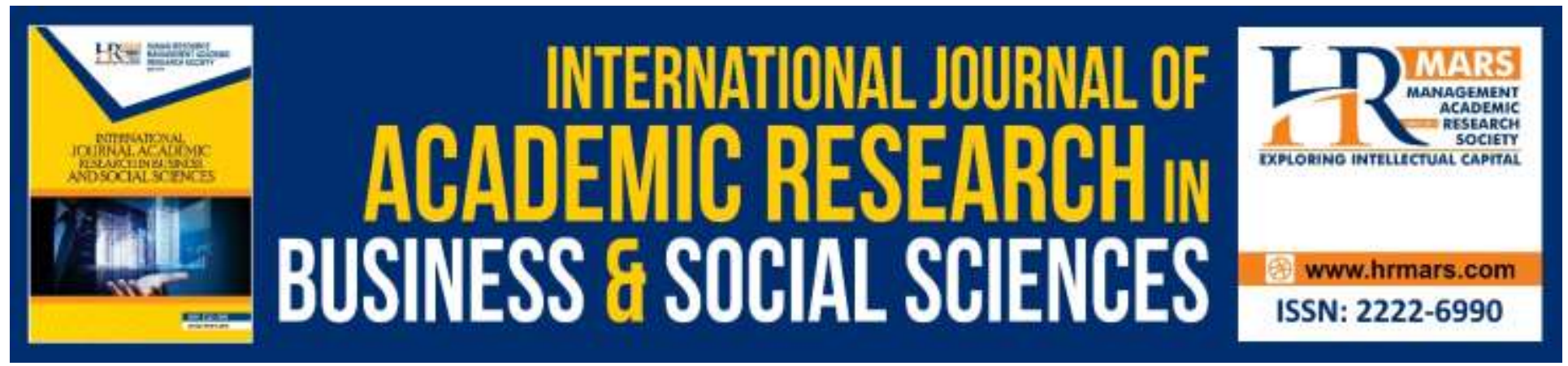

\title{
Evaluating the Awareness of Fine Motor Skills in Teaching and Learning for Students with Special Education Needs (Learning Disabilities) among Teachers
}

Farizan Binti Che Musa, Noor Aini Binti Ahmad

To Link this Article: http://dx.doi.org/10.6007/IJARBSS/v9-i11/6649

DOI: 10.6007/IJARBSS/v9-i11/6649

Received: 13 October 2019, Revised: 29 October 2019, Accepted: 03 November 2019

Published Online: 30 November 2019

In-Text Citation: (Musa, Ahmad, 2019)

To Cite this Article: Musa, F. B. C., Ahmad, N. A. B. (2019). Evaluating the Awareness of Fine Motor Skills in Teaching and Learning for Students with Special Education Needs (Learning Disabilities) Among Teachers. International Journal of Academic Research in Business and Social Sciences, 9(11), 1213-1220.

Copyright: (C) 2019 The Author(s)

Published by Human Resource Management Academic Research Society (www.hrmars.com)

This article is published under the Creative Commons Attribution (CC BY 4.0) license. Anyone may reproduce, distribute, translate and create derivative works of this article (for both commercial and non-commercial purposes), subject to full attribution to the original publication and authors. The full terms of this license may be seen at: $\underline{\text { http://creativecommons.org/licences/by/4.0/legalcode }}$

Vol. 9, No. 11, 2019, Pg. 1213 - 1220

Full Terms \& Conditions of access and use can be found at http://hrmars.com/index.php/pages/detail/publication-ethics 


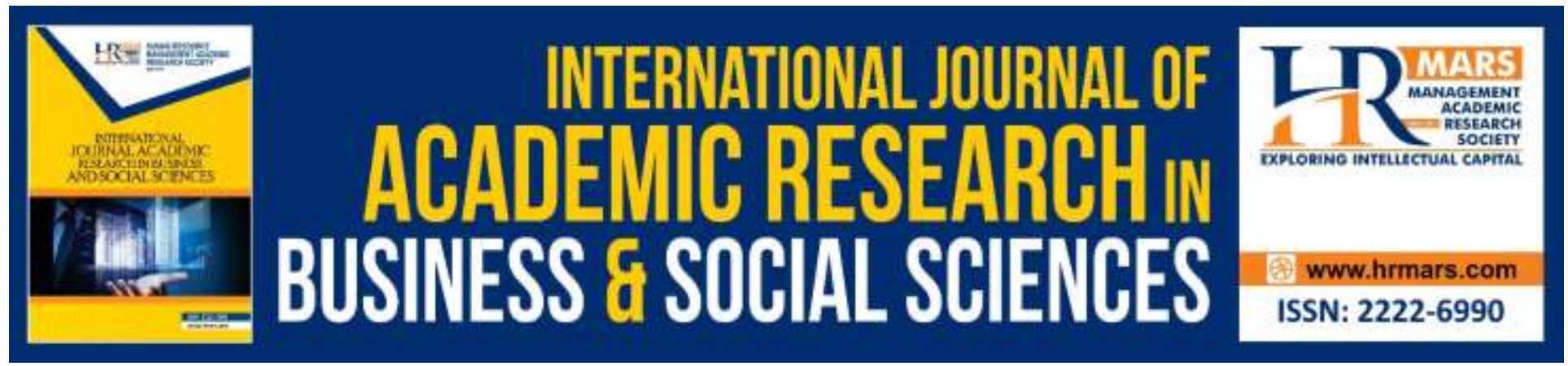

\title{
Evaluating the Awareness of Fine Motor Skills in Teaching and Learning for Students with Special Education Needs (Learning Disabilities) Among Teachers
}

\author{
Farizan binti Che Musa, Noor Aini Binti Ahmad \\ Department of Special Education, Faculty of Human Development, Universiti Pendidikan Sultan \\ Idris, Malaysia.
}

\begin{abstract}
Fine motor skill is an essential element for everyday life and a basic need in education and needed to be reinforced from early childhood. It is important for teachers to be aware of the skill in order to deliver impactful teaching and learning sessions. Therefore, this research is undertaken to evaluate the level of awareness among teachers and to see whether are there any significance in attending courses or workshops towards the impact of adapting fine motor skills in teaching and learning sessions for students with special education needs (learning disabilities). A total of 204 primary school teachers that are teaching students with special education needs (learning disabilities) under the Integrated Special Education Program (PPKI) of Federal Territory of Kuala Lumpur were chosen using survey method. The Research Findings showed that there is a high level of awareness among teachers with total average mean score (mean=44, $\mathrm{sp}=0.56$ ). The null hypothesis is accepted. In conclusion, there is no significant min difference in the level of awareness whether a teacher attend or does not attend a course or workshop regarding fine motor skill. Therefore, self-awareness plays a vital role as it is the teacher's initiative to improve the level of awareness of the importance of fine motor skills via knowledge and experience exchange and transfer.
\end{abstract}

\section{Introduction}

In Malaysia, particularly special education teachers are allowed to improvise and restructure their curriculum plans according to the students' abilities as mentioned in the Education Act (1996). Under the Education Rules (Special Education) 2013, Special Education Curriculum means a specially developed curriculum and any form of skills training that are appropriate and beneficial to students with special education needs. 
Fine motor skill is an essential element in daily lives and the foundation for academic excellence. Fine motor skills must be developed from an early childhood stage in order for students to be able to master it naturally (Arshad, 2012). Children indirectly are always using the fine motor skill as it has interrelation with the nerves that are used in their daily lives (Roebers, 2014).

Therefore, the increasing level of awareness among teachers towards students with learning disabilities and special education students contribute to the lesson plans and pedagogical approach (Ylonen \& Norwich, 2013). Meticulous lesson planning by regarding the importance and the needs as well as flexible teaching approach must be adapted in teaching students with special education needs (Lerkkanien, Kikas, Pakarinen, Poikonen \& Nurmi, 2013).

In this research, the level of awareness towards fine motor skill in teaching and learning for students with special education need (learning disabilities) among teachers is evaluated and the significance of attending a course or workshop regarding fine motor skill is also observed.

\section{Literature Review}

The literature reviews in this research are fine motor skill of students with special education needs (learning disabilities) and teachers' awareness.

\section{Fine Motor Skill of Students with Special Education Needs (Learning Disabilities)}

The main teaching activities in early childhood curriculum have to be focused towards the development of fine motor skills that involves hand-eye coordination and small muscles control that functions to cut, grasp small objects, and buttoning-up clothes (Bhatia, Davis \& ShamasBrandt, 2015). Mastering fine motor skills such as cutting, pasting, colouring, writing and folding will lay a strong foundation for students to improve their academic abilities (St John, 2013).

Fine motor skill involves smaller muscles like the hands and fingers in activities such as eating with cutleries, hand-drawing, cutting with scissors and writing (Kim, Carlson, Curby and Winsler, 2016). Fine motor could be seen clearly when there are precise movement formed with hands, fingers, writing utensil during a writing activity (Datchuk, 2015).

In conclusion, fine motor skill is a basic functionality in performing daily as well as academic tasks. Hand-eye coordination and finger movement activities including must be practiced and reinforced daily in order to master this important skillset.

\section{Teachers' Awareness}

The difficulties in understanding students with learning disabilities in providing all needs and skills are undeniable, thus, a teacher's attitude and motivation is essential in order to improve teaching professionalism by taking initiatives to attend courses and trainings (Juliet \& Ida, 2013). Trainingin-service is important for professional and commitment development in an organization (Celebi, Ozdemir \& Elicin, 2014). Teaching and learning sessions affect the level of awareness for the needs of students with special education needs among teachers (Norwich \& Ylonen, 2012).

Teachers are able to take the initiative to self-learn to increase professionalism of their teaching method (Neve, Devos \& Tuytens, 2015). Teachers' understanding towards self-believe 
in own capabilities would increase students' performance (Takahashi, 2011). The increasing level of awareness among teachers towards students with learning disabilities and special education students contribute to the lesson plans and pedagogical approach (Ylonen \& Norwich, 2013).

In conclusion, awareness is a self-infliction and is not necessarily obtained via courses and workshops, but through readings and self-initiatives as well as via knowledge and experience exchange amongst fellow teachers. This will indirectly affect teaching and learning sessions and the students.

\section{Methodology}

In this study, the researcher used the survey method with questionnaire as the main instrument. Data from the questionnaire is used to evaluate the level of awareness of fine motor skills in teaching and learning for students with special education needs (learning disabilities) among teachers. Data from the survey is used to validate the research.

\section{Research Findings}

Respondents are 204 primary school teachers that are teaching students with special education needs (learning disabilities) under the Integrated Special Education Program (PPKI) of Federal Territory of Kuala Lumpur. The findings are based on level of awareness towards fine motor skill in teaching and learning for students with special education need (learning disabilities) among teachers and the significance of attending a course or workshop regarding fine motor skill. 


\section{Section A: Demographic Data}

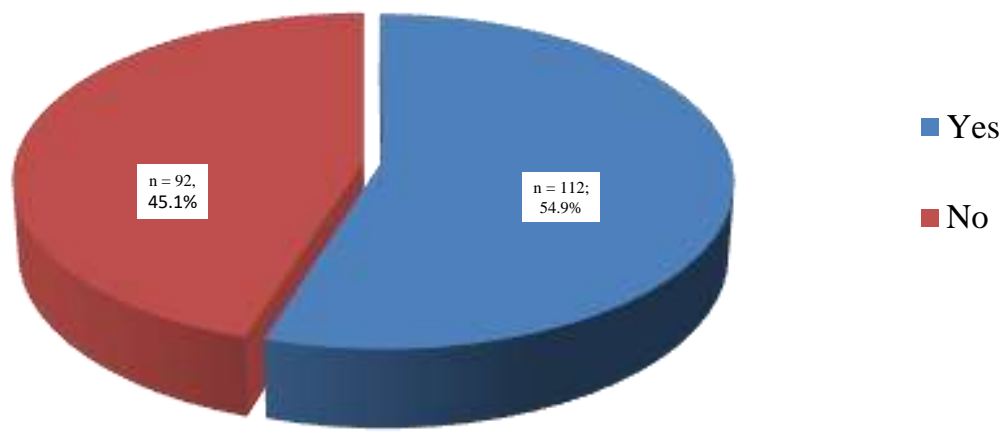

Chart 1 Respondent distribution in attending course or workshop regarding fine motor skill

Chart 1 shows the respondent distribution in attending course or workshop regarding fine motor skill. 92 respondents (45.1\%) have never attended any course regarding fine motor skill and 112 respondents (54.9\%) had attended the course or workshop at least once. This shows the majority of teachers have attended courses or workshops regarding fine motor skills.

\section{Section B:}

The Level of Awareness of Fine Motor Skills in Teaching and learning for Students with Special Education Needs (Learning Disabilities) among Teachers

The research findings showed that the level of awareness of fine motor skills in teaching and learning for students with special education needs (learning disabilities) among teachers is high. The total average mean score (mean=4.44, $s p=0.56$ ). Item mean score ranges from 4.11 to 4.70.

Five items with the highest mean score are as follows. First is item B17 (mean 4.70, $\mathrm{sp}=0.48$ ) which is buttoning-up clothes and tying-up shoes. Then is item B1 (mean 4.66, $\mathrm{sp}=0.52$ ) which is to overcome writing speed problem, followed by item B9 (mean $4.62, s p=0.53$ ) which is to overcome problems that deter students from writing. The fourth is item B13 (mean 4.60, $\mathrm{sp}=0.57$ ) which is shirt buttoning activities that involve efficient use of all hands and fingers, and lastly is item B15 (mean 4.58, sp=0.57) which is activities to practice finger movements such as clay modeling. 
INTERNATIONAL JOURNAL OF ACADEMIC RESEARCH IN BUSINESS AND SOCIAL SCIENCES

Vol. 9, No. 11, November, 2019, E-ISSN: 2222-6990 @ 2019 HRMARS

The Significance of Attending a Course or Workshop Regarding Fine Motor Skill

A t-test was done to evaluate any significance between teachers' self-awareness regarding fine motor skill and awareness by attending a course or workshop regarding fine motor skill.

Table 1

T-test Analysis Between Self-awareness and Awareness by Attending a Course

\begin{tabular}{ccccccc}
\hline Variable & Course & Mean & $\begin{array}{c}\text { Standard } \\
\text { Deviation }\end{array}$ & $\begin{array}{c}\text { DK } \\
(\mathbf{n}-\mathbf{2})\end{array}$ & t-value & p-value \\
\hline $\begin{array}{c}\text { Level of } \\
\text { Awareness }\end{array}$ & Yes & 4.475 & .335 & 202 & 1.393 & \\
& No & 4.402 & .413 & & & $0.165^{*}$ \\
\hline
\end{tabular}

Significant alpha value $(\alpha)=0.05^{*}$

In total, the findings showed that all 204 respondents have a high level of awareness of the importance of fine motor skill in teaching and learning sessions. Average mean for the awareness of respondents that attended fine motor skill course at least once is 4.475 , whereas the level for those who has never attended any course is 4.402 . The mean difference is 0.073 . Positive t-value signifies that the level of awareness of those who attended course regarding fine motor skill at least once is higher than those who do not.

The value of $t=1.393$ with degree of freedom (df) is 202 . Sig. value (2-tailed) is 0.165 , which is greater than 0.05 , thus the null hypothesis (the mean of the two groups are significantly different) is accepted. In conclusion, there is no significant mean difference in the level of awareness of fine motor skills between teachers who attended course regarding fine motor skill at least once with the teachers who do not.

\section{Discussion}

The research findings are supported by a statement; writing skill is one of the components of fine motor skill that uses small muscles such as the fingers and writing is a complex process (Mahfuzah, 2014). The five highest mean score items from the research finding showed a high level of awareness towards fine motor skill in teaching and learning for students with special education need (learning disabilities) among teachers where fine motor skills are not only focused on academic tasks but also on daily activities. Children indirectly are always using the fine motor skill as it has interrelation with the nerves that are used in their daily lives (Roebers, 2014).

The difficulties in understanding students with learning disabilities in providing all needs and skills are undeniable, thus, a teacher's attitude and motivation is essential in order to improve teaching professionalism by taking initiatives to attend courses and trainings (Juliet \& Ida, 2013). Although the t-test did not correspond to the above statement, but there is a 
statement that supports the research findings which is; reflective practice does not only increase pedagogical knowledge, self-awareness and self-perception of a teacher, but also a form of sustainable professional development (Sanchez \& Borg, 2014).

The questionnaire used in this study is used to evaluate the level of awareness towards fine motor skill in teaching and learning for students with special education need (learning disabilities) among teachers. However, further improvement should be made to the survey instrument by detailing the activities and importance of fine motor skills applied in teaching. The flexibility of teaching aids should be improved to fit the needs of students with special education needs (learning disabilities) in order to further strengthen the research findings.

\section{Conclusion}

The level of awareness towards find motor skills must be cultivated among teachers to produce a fun and engaging teaching and learning session. The awareness can be a self-infliction and a self-initiative to improve the effectiveness of teaching. The impact may not me maximum at all sessions, but the optimal developmental pace may effect not only the students, but also to the teacher in improving both academic tasks and daily activities of students. For students with special education needs (learning disabilities) at primary school level, fine motor skill is an essential component to be mastered in order to improve learning. The learning curve for students with special education needs are not only in terms of academic, but also in terms of daily activities so that they would be able to be independent and become a strong part of the society.

\section{Corresponding Author}

Farizan binti Che Musa

Department of Special Education

Faculty of Human Development

Universiti Pendidikan Sultan Idris

Perak Malaysia.

Email: izan_fcm@yahoo.com

\section{References}

Bhatia, P., Davis, A. \& Shamas-Brandt, E. (2015) Educational Gymnastics: The Effectiveness of Montessori Practical Life Activities in Developing Fine Motor Skills in Kindergartners. Early Education and Development. 26 (4),594-607.

Celebi, M., Ozdemir, H., \& Elicin, O. (2014). Studying Level of Awareness of Teachers in terms of Their Lifelong Learning Skills. Procedia - Social and Behavioral Sciences 116, 2030-2038.

Datchuk, S. (2015). Teaching Handwriting to Elementary Students With Learning Disabilities A Problem-Solving Approach. Teaching exceptional children. 48(1):19-27.

Juliet, E., \& Ida, M. (2013). A statewide survey of special education directors on teacher preparation and licentiate in autism spectrum disorders: a model for university and state collaboration. International Journal of Special Education 28, (1):4-13 
Kim, H., Carlson, A. G., Curby, T. W., \& Winsler, A. (2016). Relations among motor,social,and cognitive skills in pre kindergarten children with developmental disabilities. Research in Developmental Disabilities 53-54, 43-60.

Lerkkanen, M. K., Kikas, E., Pakarinen, E., Poikonen, P. L. \& Nurmi, J. E. (2013). Mothers' trust toward teachers in relation to teaching practices. Early Childhood Research Quarterly 28, 153- 165.

Zainol, M. (2014). Panduan Terapi Carakerja Untuk Murid Istimewa. Malaysia:Wilayah Persekutuan Putrajaya.

Arshad, M. (2012). Pendidikan Literasi Awal Kanak-Kanak. Teori dan Amali. Perak:UPSI.

Neve, D. D., Devos, G., \& Tuytens, M. (2015). The Importance of Job Resources and Self-Efficacy for Beginning Teachers' Professional Learning In Differentiated Instruction. Teaching and Teacher Education. 47, 30-41.

Norwich, B., Ylonen A. (2013). Design based research to develop the teaching of pupils with moderate learning difficulties (MLD): Evaluating lesson study terms of pupil, teacher and school outcomes. Teaching and Teacher Education 3, 162-173.

Roebers, C. M. (2014). The relation between cognitive and motor performance and their relevance for children's transition to school: A latent variable approach. Human Movement Science 33, 284-297.

Sanchez, H. S., \& Borg, S. (2014). Insights into L2 teachers' pedagogical content knowledge: A cognitive perspective on their grammar explanations. System 44, 45-53.

John, S. (2013). Factoring In Fine Motor: How Improving Fine Motor Abilities Impacts Reading and Writing. Illinois Reading Council Journal 41, 4.

Takahashi, S. (2011). Co-Constructing Efficacy: A "Communities of Practice" Perspective on Teachers' Efficacy Beliefs. Teaching and Teacher Education 27, 732-741.

Ylonen, A., \& Norwich, B. (2012). Using Lesson Study to develop teaching approaches for secondary school pupils with moderate learning difficulties: teachers' concepts, attitudes and pedagogic strategies. European Journal of Special Needs Education, 27:3, 301-317. 